\title{
Kan man lære at skifte gear? En multimodal tilgang til plot i den litterære tekst
}

\author{
ALEXANDRA HOLSTING, CINDIE AAEN MAAGAARD OG \\ NINA NØRGAARD
}

\begin{abstract}
Med udgangspunkt i den multimodale socialsemiotik præsenterer denne artikel en multimodal tilgang til narrativ med særligt fokus på plot i den litterære tekst. Vi argumenterer for, at plot som en strukturering af tekstens begivenheder er særligt kendetegnende for den litterære tekst, og at det realiseres multimodalt gennem billede, grafik, sprog, layout og typografi. Gennem en eksemplarisk analyse af Dorthe Nors' roman Spejl, skulder, blink viser vi dels den multimodale socialsemiotiks udsigelseskraft i forhold til en roman, der ikke eksplicit fremhæver sin multimodalitet, dels de analytiske fordele ved at inddrage plot som et helt centralt element. Artiklens primære bidrag til det socialsemiotiske multimodale forskningsfelt består $i$ at inddrage plotbegrebet i den multimodale analyse og derved belyse, hvordan den narrative kategori plot, der ofte opfattes som en rent sproglig konstruktion designet af forfatteren, kan ses som resultatet af valg truffet gennem forskellige semiotiske ressourcer og på forskellige realisationsniveauer.
\end{abstract}

EMNEORD: multimodal socialsemiotik, litterær analyse, narrativ, plot, multimodal realisering af plot

\section{INTRODUKTION}

Denne artikel præsenterer en multimodal tilgang til narrativ med særligt fokus på plot i en litterær kontekst. Udgangspunktet er den multimodale socialsemiotik (Halliday 1978; Kress og van Leeuwen 1996, 2001), hvis analyseapparat i stort omfang er blevet anvendt på tekster, der eksplicit benytter sig af ressourcer udover sprog ( $\mathrm{fx}$ billeder, typografi, farve) til deres realisering af betydning. Analyseredskaberne er overvejende blevet anvendt til at analysere fagtekster, omend multimodal litterær analyse - den multimodale stilistik - inden for de se- 
neste år også har etableret sig som forskningsfelt (jf. Gibbons 2012, Luke 2013, Nørgaard 2019). Også her gennemføres analyserne oftest på tekster, der er eksplicit multimodale, og fokus er typisk rettet mod de ovennævnte ressourcer. Imidlertid beskæftiger disse analyser sig ikke med plot som et element, der er karakteristisk for den (narrative) litterære tekst. I denne artikel vil vi via en eksemplarisk analyse dels vise den multimodale socialsemiotiks udsigelseskraft i forhold til en roman, der ikke eksplicit fremhæver sin multimodalitet (i forlængelse af Nørgaard 2019), dels vise de analytiske fordele ved at inddrage plot som et centralt element.

Vi fokuserer på plot, fordi det er et særkende for den litterære tekst. Plot forstår vi overordnet som en strukturering af fortællingens begivenheder, igennem hvilken der skabes forståelse og forventninger hos læseren over tid (fx Brooks 1984, Kukkonen 2014a, 2014b, Sternberg 1978, 2001). Vores multimodale tilgang betoner, at plot ikke kun udfoldes sprogligt, men også gennem brug af andre ressourcer. Ydermere ser vi plot som noget, der rækker ud over forfatterens sproglige valg, og som noget, der skabes af romanen som multimodalt artefakt. Normalt anskues bogens omslag fx som adskilt fra den egentlige tekst, som "paratekst" og "en tærskel" til bogen (Genette (1997 [1987])). I modsætning hertil betragter vi bogomslaget som en integreret del af romanen og argumenterer for, at plottet - og dermed forståelses- og forventningsprocessen - allerede begynder her.

Artiklens analyseobjekt er Dorthe Nors' roman Spejl, skulder, blink (2016) om Sonja, der er midt i fyrrerne, bor i København og på fortællingens handlingsniveau kæmper med at lære at køre bil, mens hun også på et mere eksistentielt niveau har problemer med at "skifte gear", og sidder fast i livet. De bogstavelige og overførte betydninger af metaforen "at skifte (eller ikke skifte) gear" udfoldes i to plottråde: dels en beskrivelse af begivenheder på et aktuelt nutidsplan, dels Sonjas tankespring til faktuelle og forestillede begivenheder uden for dette, hvor fortid og nutid væves sammen. Sonja er vokset op i Balling på den jyske hede, og romanen undersøger, hvad det vil sige ikke at føle sig hjemme, bogstaveligt og metaforisk. Ensomheden og tomheden skildres både gennem mislykkede relationer til hendes bekendte i København - kørelæreren Jytte, køreskoleejeren Folke, veninden Molly 
og massøren Ellen - og gennem erindringer om moderen og søsteren Kate, og længslen efter den landlige hjemstavn.

Som det vil fremgå af vores analyse, afspejles Sonjas manglende fremdrift i romanens form. Da vi af pladshensyn ikke kan inddrage hele romanteksten, fokuserer vi på det, der vil være læserens vej ind $\mathrm{i}$ romanen - bogomslagets forside og kapitel 1 - og undersøger, hvordan plottet her realiseres multimodalt gennem billede, grafik, sprog, layout og typografi.

Vi belyser ikke blot, hvordan den litterære teksts plot konstrueres multimodalt, men demonstrerer desuden anvendeligheden af Kress og van Leeuwens (2001) stratificerede syn på betydning som noget, der både skabes gennem forskellige semiotiske ressourcer og på flere niveauer (diskurs, design, produktion, distribution). I romanen skabes betydning ad flere omgange og af flere aktører (forfatter, redaktør, grafisk designer, trykker). Man kan således fx tale om forfatterens diskurs og design af den overvejende sproglige narrativ, der i produktionen af romanen kombineres med diskurs-, design- og produktionsvalg taget af andre aktører på forlag og trykkeri. I analysen fokuserer vi ikke på, hvem der har taget hvilke valg, men på den samlede multimodale betydning, der er resultatet af disse valg, og dermed på det multimodale artefakt, der tilbydes læseren til løbende fortolkning.

\section{ET KORT RIDS AF DEN MULTIMODALE SOCIAL- SEMIOTIK}

Den multimodale socialsemiotik bygger på Hallidays (1994) systemisk funktionelle lingvistik (SFL) og opstiller grammatiske beskrivelser af andre semiotiske ressourcer med udgangspunkt $i$ en række af hans teoretiske koncepter for sprog (fx Kress og van Leeuwen 1996, 2002 og van Leeuwen 2006, 2011). Tilgangen er karakteriseret ved et tværgående syn på betydning, hvorved betydninger, der etableres af forskellige semiotiske ressourcer (fx sproglige, visuelle, typografiske), anskues ud fra den samme synsvinkel. Dermed trækker især den visuelle analyse ikke blot på samme terminologi, men også på samme koncepter (metafunktion, stratifikation, system etc.) som SFL. Det fælles udgangspunkt muliggør konsistente analyser på tværs af semiotiske ressourcer, hvorpå man kan basere et samlet udsagn om den multimodale teksts betydning. 
Hallidays påstand er, at sproget simultant skaber tre typer betydning: ideationel (der opdeles yderligere i eksperientiel og $\operatorname{logisk}{ }^{1}$ ), interpersonel og tekstuel. I forlængelse heraf præsenterer Kress og van Leeuwen (1996) redskaber til at beskrive, hvordan betydningsskabende visuelle ressourcer ligeledes er metafunktionelt organiseret. Fælles for beskrivelsen af de forskellige semiotiske ressourcers grammatikker er, at de anskues paradigmatisk (systemisk) som valg. Teksten kan dermed ses som et resultat af de valg, dens afsender(e) har truffet inden for de anvendte ressourcer.

Den multimodale socialsemiotiks beskrivelsesapparat er omfattende. Det har den fordel, at det muliggør en multimodal analyse, der er solidt forankret i tekstens sproglige og visuelle valg og karakteriseret ved sin detaljeringsgrad, systematik og replicerbarhed.

SFL's sproglige analyse består på grammatisk niveau i at udskille den grammatiske enheds eksperientielle, interpersonelle, tekstuelle og logiske strukturer. I den eksperientielle analyse identificeres forskellige procestyper og tilknyttede participanter. Den interpersonelle analyse omfatter bl.a. sætningsmodus og modalitet, mens den tekstuelle analyse afdækker sætningens tematiske struktur. De logiske strukturer iagttages i parataktiske og hypotaktiske sætningskomplekser (der i et vist omfang svarer til perioder, jf. fx Galberg Jacobsen og Skyum-Nielsen 2007), hvor sætningsstrukturer forbindes fx temporalt, kausalt, additivt eller adversativt.

Visuel eksperientiel betydning angår billedets repræsentation af verden og analyseres i relation til de participanter, der ses på billedet, processerne, som disse participanter indgår i, samt de omgivelser, hvori de er repræsenteret. Dette kan udbygges med observationer om, hvorledes participanterne kategoriseres biologisk ( $\mathrm{fx}$ hudfarve og aldersbetingede træk) og kulturelt (fx påklædning og frisure). Interpersonel betydning angår beskuerens positionering $\mathrm{i}$ forhold til de repræsenterede participanter og analyseres ved hjælp af blik, distance, perspektiv og modalitet. Kompositionel betydning refererer til billedets komposition i forhold til de forskellige elementers placering i billedet, deres indbyrdes relatio-

1 I den sproglige analyse indebærer opdelingen, at sætningsanalysen identificerer eksperientielle roller, mens analysen af komplekse sætninger afdækker logiske betydninger. En lignende skelnen etableres typisk ikke $\mathrm{i}$ den visuelle analyse, hvor begreberne bruges synonymt. 
ner samt tilskrivning af visuel vægt til udvalgte elementer. Denne type betydning analyseres ved hjælp af systemerne informationsvardi (top/ bund, venstre/ hojre, center/margin), framing, linking og saliens.

En fuld multimodal analyse af Nors' roman på baggrund af ovenstående vil være omfangsrig. I vores analyseafsnit fokuserer vi derfor på de aspekter, der er relevante for undersøgelsen af romanens plot.

\section{PLOT SOM TEKSTENS DESIGN OG LEDETRÅD FOR L/ESEREN}

Som litterært værk er Nors' roman kendetegnet ved, at tekstens organisering af begivenhederne spiller en central rolle for de betydninger, der skabes, som romanen skrider frem. Derfor betragter vi begrebet plot som nødvendigt for vores analyse af de multimodale realiseringer af romanens betydninger. Skønt andre studier af fx grafiske fortællinger (Kukkonen 2011) har koblet dette narratologiske begreb til en socialsemiotisk multimodal tilgang, mangler denne kobling i analyser af romaner, da plot dér typisk ses som et sprogligt fænomen. Vi vil imidlertid vise, hvordan flere semiotiske ressourcer realiserer romanens plot og dermed lægger op til forskellige udledninger og reaktioner fra læserens side.

Narratologien har en lang fagtradition, der beskæftiger sig med begrebet plot (Kukkonen 2014b). Vi fokuserer i det følgende på de aspekter, der er nødvendige for at forstå, hvordan romanen som artefakt skaber forventninger hos læseren, herunder to af narratologiens syn på plot: på den ene side plot som en statisk struktur og på den anden side plot som en dynamisk processuel strukturering (Kukkonen 2014b). I den klassiske narratologis tekstbaserede tilgang har det analytiske fokus typisk været på plot som struktur: en konfiguration, ofte kaldet diskurs eller sjuzet, der er et resultat af fortællerens udvælgelse af bistoriens eller fabulas materiale og arrangering af dette i et andet tidsligt forløb (Chatman 1978). Således hviler plotbegrebet på en distinktion mellem det, der sker for fortællingens karakterer (fortællingens begivenheder og hændelser), og måden, hvorpå dette bliver arrangeret. Plot forstås dermed som et mønster, der giver narrativen sammenhæng, og som fører til en overordnet, samlet betydning. Disponeringen af tid indgår i narrativens design. Hvor historiens tid er kronologisk, er diskursens 
tid frigjort fra kronologi og virkelighedens tidsprogression (Chatman 1978; Genette 1980).

Mens strukturen er en egenskab ved artefaktet, har strukturering med tilblivelsen af tekstens betydninger at gøre. Fra forfatterens side er der tale om de kunstneriske valg, der udgør tekstens design - herunder dens struktur - og de spor, der lægges ud til læseren med bestemte formål og effekter for øje (Kukkonen 2014b). Som konsekvens af vores multimodale tilgang inddrager vi i analysen desuden valg truffet af andre aktører (fx redaktør, grafisk designer og trykker). Fra læserens side indebærer strukturering den fortolkningsproces, hvorved læserens (re)konstruktion af fortællingen - herunder dens struktur - bliver til i mødet med teksten.

For os er plot som struktur nyttigt, da vi har en analytisk interesse i selve artefaktet og dets realisering af plot. Ved strukturering bevæger vi os ind på læserens reception af teksten (Sternberg 1978, 2001). Selvom en egentlig receptionsanalyse ikke er vores ærinde her, har vi øje for, at forfatterens og andres valg spiller en vigtig rolle for receptionen, da designet udlægger spor, der motiverer læserens fortolkning. I forlængelse heraf kan plottets design, logik og dynamik ifølge Brooks (1984) vække et "narrativt begær" hos læseren: en lyst til at vide mere, som driver læsningen videre (1984: 37f). I vores analyse undersøger vi, hvordan der lægges op til dette allerede på omslaget.

En narrativs interessevardi (tellability) kan ifølge narratologer som Bruner (2001) og Hühn (2008) højnes, når narrativen bryder med forventede scripts af enten adfærd, handlinger eller genre. Ifølge Herman (2003: 10) udgør scripts erfaringsbaserede repertoirer, som kan facilitere læserens arbejde med at udfylde huller i narrative repræsentationer på baggrund af spor i teksten. Interesseværdi spiller også en rolle i visuel narrativitet, dvs. billedets evne til at stimulere en narrativ fortolkning (Ryan 2004). Da et stillbillede ikke i sig selv kan berette om en sekvens af begivenheder, overlader dette et større fortolkningsarbejde til beskueren i konstruktionen af et narrativt forløb, end det typisk ses i sproglige narrativer (Ryan 2004, 2012). Billedet inviterer dermed beskueren til både at forholde sig til det, der bliver afbildet, og til at trække på sin kontekstuelle viden (om fx situationen, participanterne, formålet med billedet og billedets genre) såvel som på kulturelt etab- 
lerede scripts for menneskelig adfærd og handlinger (Maagaard 2018). Samspillet mellem billedet og den kulturelt konstruerede kontekst hjælper beskueren til at konstruere en historie, hvori det afbildede øjeblik indgår $\mathrm{i}$ et længere tidsligt forløb (Kafalenos 2001).

Et sidste aspekt af plot, vi inddrager i analysen, berører en mere kognitiv interesse for læserens emotionelle respons. Ifølge Sternberg $(1978,2001)$ kan fordelingen af historiens informationer afstedkomme tre grundlæggende reaktioner hos læseren i den mentale rekonstruktion af historiens verden i fortolkningsprocessen: overraskelse (surprise), nysgerrighed (curiosity) og spanding (suspense), der henholdsvis opstår igennem læserens genkendelse (recognition), retrospektion og prospektion. Overraskelse forekommer, når læseren opdager en fejl i sine hypoteser om handlingen. Nysgerrighed vækkes, når læseren fortolker retrospektivt og finder, at noget i de forudgående begivenheder mangler som forklaring på det, hun læser netop nu. Spænding er prospektiv og opstår, når det er uvist, om det, læseren på baggrund af plottets design forventer, rent faktisk kommer til at ske. I forlængelse heraf påpeger Kukkonen (2014a), at læsere konstant må "recalibrate their expectations in sequences of surprise, curiosity and suspense". Med vores socialsemiotiske tilgang foregiver vi ikke at vide, hvordan den enkelte læser vil reagere på teksten, men vi peger i vores analyse af Nors' roman på elementer i teksten, der inviterer til forventninger og justeringer af disse, og dermed til nysgerrighed, overraskelse og spænding.

\section{BOGOMSLAGET}

I det følgende præsenterer vi en analyse af bogomslagets forside på den første danske udgave af Spejl, skulder, blink (figur 1). Som med mange andre romaner er omslaget også denne romans mest eksplicit multimodale element, og det inviterer til analyse af både sprog, typografi og omslagsbillede og af samspillet mellem de forskellige ressourcer. Hvad angår eksperientiel og kompositionel betydning, viser omslaget den nederste del af en bildør i billedets øverste halvdel (top) samt beton nederst i billedet (bund). Desuden ses en rød sele, der sidder i klemme i den lukkede bildør. Interpersonelt giver narbilledet af bildøren selen prominens samtidig med, at detaljer som bilhåndtag og lås falder inden for billedets ramme. Betydningen af dette valg bliver 
for alvor tydelig, hvis det som analytisk greb underlægges en kommutationstest (fx Hjelmslev 1993 [1943], Barthes 1967: 65-67, Kress 2010: 89-92), hvor alternative valg inden for systemet distance overvejes. Hvis billedets eksperientielle indhold havde været repræsenteret på større afstand (tota), ville selen i døren have fyldt mindre af billedets flade og have fremstået som mindre prominent. Havde distancen derimod været mindre (ultranar), ville man ikke se bildørens håndtag og lås, som på det aktuelle omslag netop er med til at etablere, at det er en bildør, der ses på billedet. Det interpersonelle nærbillede af bildøren giver sammen med selens prominente røde farve mod baggrunden af den lyse bildør og den grå beton selen visuel vægt. Sammen gør disse valg i systemerne distance og saliens selen til billedets visuelt mest fremtrædende og dermed vigtigste participant. At selen er salient og repræsenteret som værende i klemme i døren, forøger den afbildede situations interesseværdi, fordi det bryder med gængs viden og forventning om typiske scripts for brugen af biler og seler og indikerer, at noget ikke helt er, som det bør være. Beskueren mangler viden om, hvad der er gået forud for det afbildede øjeblik, og teksten inviterer til nysgerrighed. Samtidig skabes der fremadrettet spænding om, hvilket plot der på meningsfuld vis drejer sig om en sele i klemme i en bildør.

Den visuelle repræsentation af bildøren og bogens titel, Spejl, skulder, blink, understøtter hinanden og udgør et eksempel på multimodal kohæsion. Hvor den visuelle del af kohæsionsparret skaber forventning om, at Nors' bog på en eller anden måde handler om biler, indsnævres denne betydning sprogligt af bogens titel til en kontekst, hvor nogen lærer at køre bil. I en køreskolekontekst fungerer "spejl, skulder, blink" som huskeremse, når eleverne skal lære at dreje og dermed skifte retning, hvilket involverer, at man orienterer sig bagud i bilens spejle og over skulderen. Efterhånden som plottet i Nors' roman udfolder sig sprogligt, viser det sig, at netop dette greb - at skifte retning - i bogstavelig såvel som overført betydning volder problemer i hovedpersonens liv, men også at Sonja i meget høj grad orienterer sig bagud i sit liv - mod sin familie og sin opvækst - i forsøget på at skifte retning. Dermed bidrager den sproglige udfoldelse af plottet til retrospektivt at indsnævre det betydningspotentiale, der etableres på omslaget.

Ud over de sproglige elementer, der udgør bogens titel, forfatter, 


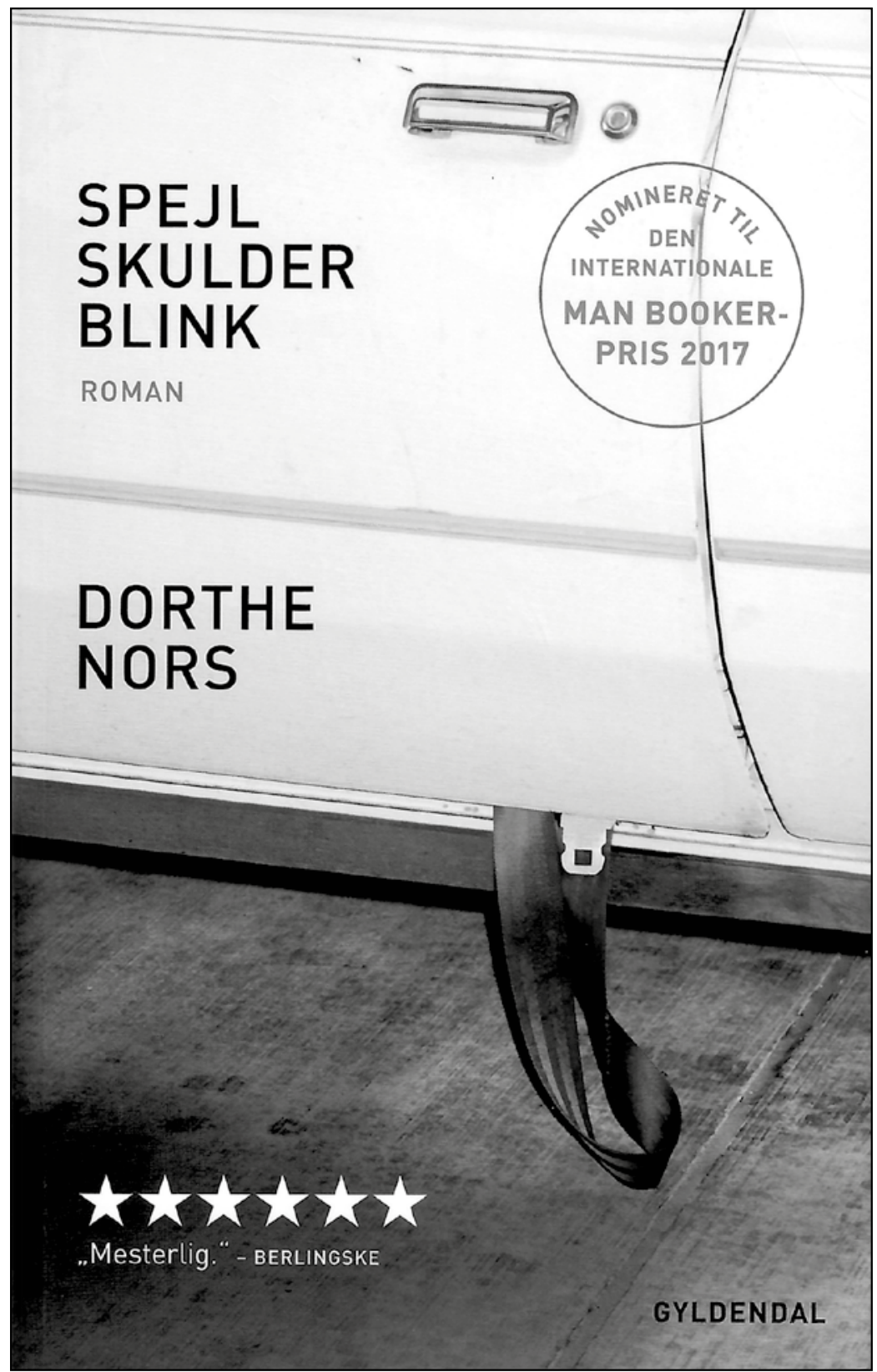

FIGUR 1. FORSIDE AF BOGOMSLAG, SPEJL, SKULDER, BLINK, GENGIVET MED TILLADELSE FRA GYLDENDAL. TRYKT GENGIVELSE I SORT-HVID, FARVEUDGAVE KAN SES I TIDSSKRIFTETS ONLINEUDGAVE. 
forlag og genre, rummer omslaget desuden et grafisk element, der ligner et stempel. En nærmere undersøgelse afslører, at dette element er for regelmæssigt i sin udførelse til at være et rigtigt stempel, og at betydningen 'stempel' realiseres af en kombination af grafik, farve og tekst. Hvor tekst indrammet af en (ofte rød) cirkel som her kan konstruere den generelle betydning 'stempel', præciserer teksten stemplets mere specifikke betydning, der i en litterær kontekst er et kvalitetsstempel, nemlig at romanen er "NOMINERET TIL DEN INTERNATIONALE MAN BOOKER-PRIS 2017'. Betydningen 'kvalitet' skabes ligeledes af de seks grafisk realiserede stjerner nederst på bogens omslag ledsaget af teksten '"Mesterlig.' - BERLINGSKE", som mange læsere vil genkende som uddrag af en boganmeldelse.

En logisk følge af vores værkcentrerede, multimodale tilgang til plot er også at inddrage den betydning, der skabes af stemplet og boganmeldelsen på romanens omslag $i$ vores analyse. Nomineringen til Man Booker-prisen er tydeligvis ikke en del af bogens oprindelige betydning, da romaner først bliver nomineret til litterære priser efter deres første udgivelse. Ej heller er den en del af romanens univers og handling. I stedet skaber 'stemplet', den positive anmeldelse fra en stor landsdækkende avis og informationen om, at romanen er udkommet på et bestemt forlag - her Gyldendal - en forventning om romanens kvalitet (Squires 2007: 71-82) og kan være med til at farve læserens videre vej ind i dens fortælling. Tilsammen signalerer disse elementer, at romanen er et skønlitterært værk, hvor formen er velovervejet og har kunstnerisk værdi, samt at indholdet behandler seriøse (og ikke trivielle) emner.

Mens inddragelse af bogomslaget $i$ analysen af romanens plot fra et mere traditionelt analytisk perspektiv - $\mathrm{fx}$ et nykritisk, narratologisk eller stilistisk - kan synes kontroversiel, er et argument for dette bl.a., at forskellige omslag til den samme roman skaber forskellige betydninger (jf. kommutationstesten). På det engelske omslag (Pushkin Press, 2017) ${ }^{2}$ kombineres titlens køreskoleremse fx med en grafisk

2 Grundet ophavsrettigheder kan de internationale forsider desværre ikke gengives i artiklen. Ved udgivelsen af nærværende artikel kunne de udenlandske omslag ses på følgende websteder. Engelsk omslag: https://www.pushkinpress.com/product/mirror-shoulder-signal. Hollandsk omslag: http://uitgeverijpodium.nl/Recent-verschenen/book/603/Spiegel-spiegel-schouder. Tysk omslag: https://keinundaber.ch/de/literary-work/rechts-blinken-links-abbiegen. 
fremstilling af en bildør, hvor distancen til døren er større end på det danske omslag, så også bilens vindue og en silhuet af dens fører kan ses. Eksperientielt kategoriseres bilens fører kulturelt som kvinde via frisure og påklædning, hvorved hovedpersonens køn allerede specificeres på bogens omslag. På dette omslag er det endvidere kvindens kjole - og ikke den kønsneutrale sele - der sidder i klemme i bildøren med mulig kønnet betydning til følge: 'en kvinde lærer at køre bil, og der er noget, der ikke er, som det burde være'. Det hollandske omslag (Podium, 2017) viser som det engelske en kvinde i en bil, men her skaber den kulturelle kategorisering via frisure og hårfarve (langt blondt eller blonderet hår) en medbetydning, der måske vil aktivere et 'blondinen-kan-ikke-køre-bil'-script i takt med, at Sonjas manglende køreevner udfoldes på romanens første sider. Lidt overraskende modsiges billedets eksperientielle betydning senere sprogligt af beskrivelsen af Sonja som "kortklippet" (Nors 2016: 37). Det kan sluttelig nævnes, at forsidebilledet på romanens tyske omslag (Kein \& Aber Verlag, 2016) er et nærbillede af en åben bildør med et par fødder, der stikker ud, og en hvid gås eller svane, der står med hals og hoved skjult af døren. I denne udgave af Nors' roman skaber omslaget nysgerrighed om, hvad der motiverer denne sammenstilling af bil og fugl, samt fremadrettet spænding, der dog aldrig forløses gennem et plot, der på meningsfuld måde forener de to.

Bogomslagets betydninger stammer typisk ikke fra forfatteren, men opstår senere som et resultat af valg taget $\mathrm{i}$ forbindelse med materialiseringen af forfatterens sproglige narrativ i produktionen af denne som bog (jf. Kress og van Leeuwen 2001). I vores værkbaserede multimodale tilgang til romanens plot inkluderer vi imidlertid disse betydninger $i$ anerkendelse af, at forskellige udgaver af bogomslaget aktiverer forskellige scripts - også selvom disse i nogle tilfælde er direkte misvisende i forhold til romanens sproglige indhold.

\section{KAPITEL 1}

I analysen af kapitel 1 fokuserer vi særligt på sproget (i særdeleshed på eksperientielle og logiske betydninger), men inddrager desuden layout og typografi som betydningsskabende ressourcer. Kapitlets ramme er en køretime, hvor Sonja og hendes kørelærer Jytte kører fra Frederiks- 
berg over Vesterbro til Vigerslev Allé ved Vestre Kirkegård. Dermed knyttes der direkte an til bogomslagets titel. Dette forløb, i det følgende benævnt det aktuelle nutidsplan, er skildret kronologisk, så der her er sammenfald mellem historiens begivenheder og diskursens organisering af disse. Situationerne i bilen er præget af Sonjas usikkerhed i forhold til kørslen og Jytte, der dels giver instrukser, dels overtager dele af kørslen - i særdeleshed gearskiftningen, som ellers er det, Sonja skal lære. Undervejs beretter Jytte om situationer fra sit eget liv og når også at tale $\mathrm{i}$ telefon med sin mand. Kapitlets beskrivelse af køreturen slutter med, at Jytte geråder ud $\mathrm{i}$ en verbal konflikt med føreren af en varevogn. Skildringen af køretimen afbrydes af Sonjas tanker, der vandrer til scener, der finder sted $\mathrm{i}$ andre rum og/eller til andre tider (teorilokalet på Frederiksberg, en tidligere køretimesituation, Sonjas fødeby Balling, Jyttes hjemstavn på Djursland, Jyttes barndom, Sonjas søster Kates teenageår), hvorved diskursens strukturering af tid afviger fra historiens. Til slut går Sonjas tanker til Vestre Kirkegård, hvor hun ofte søger hen i ro for biler og anden larm. Noget gådefuldt hedder det afslutningsvis: "Så ligger hun der og kan undvige" (2016: 13).

Her passer det leksikalske valg af den materielle proces undvige $e^{3}$ som udgangspunkt fint ind i det eksperientielle felt knyttet til bilkørsel og køretimer. Modsat processen dreje, der underforstås med titlen, betegner undvige ikke en intenderet og målrettet manøvre, men snarere noget, man gør for at undgå ubehageligheder. At processen undvige indgår i en kongruenskonstruktion med ligge og lokaliseres på kirkegården, indikerer, at processen ikke er knyttet til køre-bil-universet, men til romanens eksistentielle plottråd. At den herudover er konstrueret uden et objekt, skaber nysgerrighed om, hvad det er, Sonja vil undvige. Dette antydes i kapitel 1, men udfoldes først for alvor senere i romanen.

Skiftene fra det aktuelle nutidsplan til de øvrige planer etableres overvejende sprogligt, men også layout og typografi spiller en rolle (se Nørgaard 2019: 67-68 for distinktionen mellem disse). I forhold til layout er det påfaldende, at historiens skift sjældent følges af et skift

3 I analysen fastholder vi SFL's eksperientielle procestypologi med dens overordnede inddeling i materielle, relationelle, mentale og verbale processer (der på sætningsniveau realiseres gennem verbalerne); derimod undgår vi SFL-terminologien i forhold til participanter og fastholder her en mere udbredt grammatisk terminologi. 
i afsnit, men typisk etableres inden for et sådant; fx i romanens andet afsnit (2016: 6-7), der går fra bilen til en beskrivelse af Sonjas søsters vilde ungdom, tilbage til bilen og derefter beskriver Jyttes opførsel på køreskolen. Herigennem sættes de instruktioner, der $\mathrm{i}$ andre teksttyper normalt ligger i afsnitsopbygning, ud af kraft; læseren kan ikke regne med, at tekstens layout afspejler historiens forløb. I stedet etablerer diskursen skiftene på andre måder, som vi vil vise nedenfor.

Typografien som betydningsressource ses først og fremmest i den udtryksmæssige modsætning mellem ikke-kursiv (som ses i hovedparten af teksten) og kursiv. Første gang, vi støder på kursiv, er i et citat:

(1) Hun [Sonja] blev også svimmel af det, og det måtte ingen opdage. Du er sådan en fighter, har mor altid sagt, og det er Sonja: hun giver ikke op. (2016: 6)

Generelt realiseres citeret tale i litterære såvel som ikke-litterære tekster enten gennem en grammatisk struktur med citatet som objekt (her for sige) eller alene gennem tegnsætning (Andersen og Holsting 2015). Typisk anvendes omkransende citationstegn eller indledende replikstreg, ofte i kombination med afsnitsskift og indryk (Jacobsen og Jørgensen 2013: 52). I (1) ses dermed et ukonventionelt eksempel på citatmarkering. Efter yderligere to citater med denne form, optræder imidlertid et fjerde i en mere konventionel form:

(2) Hendes [yttes] søn skal giftes, hendes barnebarn skal hedde noget rædderligt, svigerdatteren er dum i tøjet, og hendes svogers mors nye mands søster er lige død.

- Folk fra Thailand kan ikke køre bil.

Sonja og Jytte holder ved et lyskryds på Frederiksberg. [...]

Jytte har hånden på gearstangen, mens Sonja selv ser efter cyklister.

- Hende jeg har nu hedder Pakpao. Pakpao? GRØNT LYS!

ANDET GEAR, ANDET GEAR, CYKEL! (2016: 8-9)

Denne tilsyneladende inkonsekvens kan dog i løbet af kapitlet (og resten af romanen) afkodes, idet der formmæssigt skelnes mellem ci- 
tater, der fungerer som replikker på fortællingens nutidsplan (angivet med replikstreg og indryk), og citater, der fungerer på andre planer (angivet typografisk med kursiv). Eksemplet illustrerer desuden en anden typografisk formmodsætning mellem konventionel brug af store og små bogstaver (i overensstemmelse med dansk ortografi) og brug af udelukkende store bogstaver, der kan afkodes ikonisk som øget stemmestyrke (Nørgaard 2019: 98-99).

Romanen etablerer dermed en ikke-konventionaliseret formmodsætning mellem citeret tale i den plottråd, der foregår på det kronologisk fremadskridende nutidsplan, og citeret tale uden for denne. En sådan modsætning kan også etableres gennem sproglige valg ( $\mathrm{fx}$ tempus: råber/råbte), men at den her kodes multimodalt i en layoutmæssig og typografisk modsætning, indebærer, at den bliver visuelt observerbar for læseren, og den hiælper desuden denne til at navigere i diskursens organisering af situationer.

Altovervejende skabes betydningerne i kapitel 1, herunder skiftene i narrativens planer, sprogligt. Dette sker bl.a. gennem tempus, hvor narrativen gør brug af præsens, præteritum og perfektum. Det aktuelle nutidsplan, der overvejende skildres fortløbende, er generelt holdt $i$ præsens (jf. fx (2)), mens Sonjas tilbageblik er skrevet i præteritum:

(3) Sonjas søster Kate og svoger Frank tog kørekort i firserne. (2016: 6)

I de digressioner, der ikke leder Sonja til egentlige fortidige hændelser, bruges primært præsens:

(4) Når Sonja kommer [til køreskolen] sidder hun [ytte] inde på Folkes kontor, hun er på Facebook eller i færd med at åbne de andre elevers lægejournaler. (2016: 6-7)

I enkelte tilfælde anvendes perfektum som angivelse af fortidige situationer med relevans for nutiden (Hansen og Heltoft 2011: 696). Det ses fx i (5), hvor Sonja i tankerne har været langt borte, men bringes tilbage til bilen af Jyttes råb: 
(5) - BREMS FOR HELVEDE! KAN DU DA FOR SATAN IKKE SE DET FODGÆNGERFELT!

Jytte har bremset og gearet dem ned i første. (2016: 11)

Her er Sonja (og læseren) gået glip af bremsningen og nedgearingen og kan kun iagttage resultatet af disse. Der sker dermed et brud i det ellers fortløbende præsensbaserede handlingsforløb i bilen, der medvirker til at understrege, hvor langt væk Sonja har været $i$ tankerne.

Overgangen til tankevandringerne etableres typisk sprogligt gennem den mentale proces tanke, hvorved læseren guides, og overgangen forløber relativt gelinde:

(6) Sonja drejer til højre og tænker på, hvordan hun måske selv lyder, når hun taler i telefon med Kate. (2016: 9)

Skiftene den anden vej er derimod ofte abrupte (som i (7), der ligger i direkte forlængelse af (6)):

(7) Men hun taler næsten aldrig i telefon med Kate mere, og nu er de på vej ind på Vesterbro. (2016: 9)

I flere tilfælde er skiftene nærmest formelagtige i deres udformning: "så nu sidder hun i en bil" (2016: 6), "og nu sidder hun så i bilen" (2016: 7), "og nu nærmer de sig Vigerslev Allé" (2016: 12). Genetableringen af det aktuelle nutidsplan er generelt karakteriseret af det deiktiske $n u$ og en lokalangivelse, der enten placerer Sonja i bilen eller bilen i geografien.

Tempusmæssigt indeholder kapitel 1 en interessant afvigelse fra det beskrevne mønster. Sonjas tanker går dels til hendes egen hjemstavn i Balling (2016: 6), dels til Jyttes hjemstavn på Djursland (2016: 8). At begge stammer fra Jylland, fører imidlertid til en sammenvævning af de to steder i Sonjas senere tankevandringer:

(8) Sonja tænker på foderstofforretningen på Djursland. Hjemme i Balling havde de også sådan en. (2016: 10) 
Via Djursland kommer vi til Balling og en beskrivelse af de forandringer, sammenlægningen af landbrug har fået for egnen. Selvom stadigt færre arbejder $i$ landbruget, har landkøkkenerne dog stadig samme størrelse. Og via landkøkkenerne i Balling bringes vi atter til Djursland:

(9) Man har altid skullet rykke sig på bænken for håndens arbejde, og så har Jytte siddet der på Djursland og dinglet med benene. Det er det store frikvarter, hun er løbet hjem for at spise, og hendes fødder har ikke kunnet nå gulvet. Hun har røde ankelsokker på og en skotskternet nederdel ... . (2016: 10)

Herfra beskrives det, hvordan Jytte spiser franskbrød med puddersukker og må løbe tilbage til skolen, når klokken ringer. Hvorvidt denne situation er baseret på, hvad Jytte har fortalt om sin barndom, på hvad Sonja forestiller sig om denne, eller om der reelt er tale om Sonjas egne barndomsminder, forbliver uklart. Modsat de egentlige tilbageblik (som i (3)) er denne sekvens holdt i præsens og perfektum, hvorved de grænser mellem fortid og nutid, romanen ellers har etableret med sine tempusvalg, ophæves på samme måde, som lokaliteter og personer synes at glide ind i hinanden. Her som $\mathrm{i}$ lignende eksempler synes tempusvalg at afspejle Sonjas oplevelse af tid - dvs. fortid. Nogle gange er der en temporal distance til det erindrede (præteritum), andre gange $e r$ hun $\mathrm{i}$ fortiden (præsens).

Et af romanens mest udtalte sproglige karakteristika er dens brug af parataktiske sætningskomplekser (Hansen og Heltoft 2011: 961ff.; Halliday og Matthiessen 2013: 451-60, 472-4; Andersen og Holsting 2015), ikke mindst den additive slags etableret med konjunktionalet $g$. Disse konstruktioner er ikke blot hyppigt forekommende i romanen, men også i mange tilfælde påfaldende, fordi skiftene mellem de forskellige planer ofte etableres i sådanne parataktiske sætningskomplekser (som i (7)).

Karakteristisk for parataksen er, at den fremstiller sine sideordnede led, konjunkter, som semantisk ligevægtede (Halliday og Matthiessen 2000: 50), og samtidig som tættere forbundne end selvstændige helsætninger (Hansen og Heltoft 2011: 959), hvilket yderligere kan un- 
derbygges af ellipse. Relationen mellem konjunkterne kan specificeres leksikalsk som adversativ (men) eller alternativ (eller), kausal (for) eller konsekutiv (sä). Heroverfor signalerer og en rent additiv relation, der dermed også opfattes som den semantisk set mest elementære blandt de parataktiske relationer (Breindl m.fl. 2014: 401). Ofte kan læseren på baggrund af konteksten indtolke andre mere specifikke betydningsrelationer som fx tidslig rækkefølge, årsags- eller modsætningssammenhæng, hvilket kan understøttes og entydiggøres af konneksionsadverbialer ( $\circ g$ så, og derfor etc.), men i sig selv angiver og blot, at konjunkterne kan anskues som "Elemente einer typgleichen Menge" (Breindl m.fl. 2014: 401).

Allerede kapitlets begyndelse illustrerer den hyppige forekomst af parataktiske sætningskomplekser. (I de følgende eksempler er de enkelte perioder markeret med fortløbende hævede tal, mens de parataktisk ordnede helsætninger i hver periode er markeret med fortløbende tal i kantede parenteser):

(10) ${ }^{1}$ [1] Sonja sidder i en bil, [2] og hun har ordbogen med. ${ }^{2}[1]$ Den er tung [2] og ligger i tasken på bagsædet. ${ }^{3}[1]$ Hun er halvvejs igennem oversættelsen af Gösta Svenssons seneste krimi, [2] og hans niveau var faldende allerede i den forrige. ${ }^{4}$ [1] Hun tænkte: Det er nu jeg har råd, [2] så hun søgte efter køreskoler på nettet [3] og meldte sig til hos Folke på Frederiksberg. ${ }^{5}[1]$ Teorilokalet er lille og blåt [2] og lugter af gammel røg og omklædningsrum, [3] men det gik godt med teorien. ${ }^{6}[1]$ Ud over Folke var der kun én på Sonjas alder i lokalet, [2] og han var taget i spritkørsel, [3] så han holdt sig for sig selv. (2016: 5)

Eksemplets seks perioder har alle form af parataktiske sætningskomplekser. Tre af de parataktisk ordnede sætninger er elliptiske (2.2, 4.3, 5.2), mens de resterende er konstrueret med alle led. En enkelt (1.2) kunne ud fra grammatiske kriterier have været elliptisk konstrueret ("Sonja sidder i en bil og har ordbogen med"), eftersom subjektet i 1.1 og 1.2 har samme referent, men er det ikke (se nedenfor).

Flere af de parataktiske og-sætningskomplekser i (10) er relativt upå- 
faldende i deres sammenstilling af situationer eller forhold, fx sammenstillingen af $4.2 \mathrm{og} 4.3$, der uproblematisk tillader en temporal læsning, og 5.1 og 5.2, der begge beskriver teorilokalet. I begge tilfælde er konjunkt 2 elliptisk, hvilket understreger sammenknytningen. I andre af (10)'s parataktiske og-sætningskomplekser forekommer sammenstillingen dog påfaldende eller overraskende, fx 1.1 og 1.2. Inden for romanens univers er der tale om en kortfattet, men rammende karakteristik af Sonja, der dels er ved at lære at køre bil, dels arbejder som skønlitterær oversætter. Det første motiverer placeringen i en bil, det andet, at hun medbringer en ordbog. Sammenstillingen af de to er ikke desto mindre overraskende, fordi parataksen inviterer os til at se en sammenhæng, der på baggrund af vores generelle viden om verden ikke forekommer logisk. Bil og ordbog refererer umiddelbart til to forskellige sfærer, og det er svært at forestille sig en situation, hvor begge er relevante. I et eksperientielt perspektiv tilhører de forskellige felter, og romanen har endnu ikke haft mulighed for at etablere et sted, hvor disse felter mødes. Da læseren mangler den fornødne baggrundsviden til at udlede en forbindelse, kan det give anledning til plotmæssig nysgerrighed. At 1.2 ikke er konstrueret elliptisk (trods muligheden herfor), medvirker til at underbygge en relativ selvstændighed.

Konjunkt 1.1 knytter umiddelbart an til de spor, der udlægges, og den forventning, der etableres via bogomslagets betydninger, mens konjunkt 1.2 udgør et markeret valg. Forklaringen på ordbogen følger dog i 3.1 og 3.2, hvor oversættelsesarbejdet introduceres. Også her forekommer sammenstillingen af de to konjunkter dog overraskende. Selvom der her etableres flere kohæsive bånd mellem konjunkterne (reference: Gösta Svenssons / hans; ellipse: Gösta Svensson seneste krimi / den forrige) ender sætningskomplekset næppe, hvor vi forventer det. Det gælder bl.a. i forhold til de tidslige forhold; i forlængelse af Grices (1975) mådesmaksime, "be orderly", kan vi have en vis forventning om, at konjunkternes rækkefølge i sætningskomplekset afspejler situationernes rækkefølge i virkeligheden (jf. også Breindl m.fl. 2014: 412f.). Her er konjunkt 3.1 dog knyttet til nutidsplanet, mens konjunkt 3.2 bringer os til en fortidig situation. Dette etableres dels af tempusvalget (hhv. præsens og præteritum), dels af modifikatorerne seneste og forrige. Herudover udgør konjunkt 3.1 en neutral situationsbeskrivelse, 
mens konjunkt 3.2's bemærkning om det faldende niveau introducerer Sonjas negative påskønnelse (jf. Martin og Rose 2003: 34), og temporaladverbialet allerede tvinger læseren til at justere sin forstålse af indholdet i konjunkt 1 (se Breindl m.fl. 2014: 402f.). Hvis niveauet er faldet allerede i den forrige roman, implicerer det, at det er faldet yderligere i den seneste. Fra et narrativt perspektiv ser vi her et eksempel på, hvorledes tekstens leksikogrammatiske valg leder læseren ind $\mathrm{i}$ "a process of establishing and revising beliefs about the environment of the fictional world on the strength of the evidence at hand" (Kukkonen 2014a: 722).

Ikke alle tekstens parataktiske sætningskomplekser indebærer overraskende skift, men det er et karakteristisk træk ved romanen (i kapitel 1 såvel som senere), at skiftene typisk foregår inden for det parataktiske sætningskompleks, hvorved der i mange tilfælde etableres en overraskende modsætning mellem de forventninger, den grammatiske form etablerer, og den måde, den indholdsmæssigt udfyldes på (fx Ulbæk (2005: 36) om "ikonicitetsprincippet for mening").

Et sådant meget påfaldende skift, der samtidig trækker på udnyttelsen af typografien til at skelne mellem replikker på fortællingens forskellige niveauer, ses i (11). Sonjas tanker er tilbage ved førstehjælpskurset, hvor hun har fungeret som demonstrationsperson:

(11) ${ }^{1}$ Det var ydmygende at blive lagt i stabilt sideleje af en dreng på atten. ${ }^{2}$ [1] Hun blev også svimmel af det, [2] og det måtte ingen opdage. ${ }^{3}[1]$ Du er sådan en fighter, har mor altid sagt, [2] og det er Sonja: hun giver ikke op. ${ }^{4}[1]$ Hun burde gøre det, [2] men hun gør det ikke, [3] og så pumper I bjertet tredve gange härdt og marker efter, om vejret bliver trukket, sagde førstehjælpslæreren. (2016: 6)

Her bevæger vi os fra førstehjælpskurset, over et mere generelt tidsplan og tilbage til kurset gennem lærerens replik. Overgangen fra 4.2 til 4.3 er påfaldende, dels fordi der sker et radikalt indholdsskift, dels fordi der sker et skift i udsigelsespositionen., der umiddelbart kan afkodes pga. kursiven. Endelig er også replikken tilsyneladende selv konjunkt 2 $i$ et $g$-sætningskompleks, hvis konjunkt 1 vi aldrig ser. 
I lighed med den overraskende brug af layout ved afsnitsinddelingen, medvirker denne brug af og-paratakse til, at skiftene mellem de forskellige planer bliver abrupte, fordi den forventning, parataksen skaber om en tæt og motiveret relation mellem konjunkterne, ikke opfyldes. Dette kan føre til en fornemmelse af, at der mangler en forbindelse, hvilket igen kan knyttes til begreberne overraskelse og nysgerrighed. Overraskelse opstår, fordi vi ofte ikke ender der, hvor vi forventer det, og nysgerrighed vækkes, fordi den manglende forbindelse peger på en lakune i diskursens skildring af historiens begivenheder.

Den særprægede brug af parataktiske sætningskomplekser som domæne for skift frem og tilbage $i$ tid synes at afspejle romanens tema. At Sonjas fastlåsthed er knyttet til hendes fortid og de mislykkede relationer, underbygges af hendes tankevandringer, der gang på gang fører væk fra den aktuelle virkelighed. Omvendt resulterer de abrupte skift tilbage til nutidsplanet $i$, at noget forbliver ufortalt. Sonja undviger, før vi kan få etableret den egentlige sammenhæng. Den karakteristiske brug af og-paratakse i kombination med skift i tid bliver dermed helt centralt for den måde, hvorpå plottet bliver konstrueret i Nors' roman.

\section{KONKLUSION}

I erkendelse af at plot er centralt for den narrative litterære teksts realisering af betydning, har vi i ovenstående analyse vist, hvorledes plot kan inddrages produktivt i en multimodal analyse af en roman. Ved at anlægge dette perspektiv på Spejl, skulder, blink understreger vi, at bogen som artefakt gør brug af betydningsskabende ressourcer, der rækker ud over de rent sproglige, og at andre valg end forfatterens er med til at konstituere betydningerne. De plotmæssige spor, som lægges ud til læseren, realiseres multimodalt gennem sprog, billede, farve, typografi og layout, der tilsammen skaber forventninger om romanens form og indhold.

Som konsekvens af vores multimodale tilgang til analyse af plot bidrager vi til den eksisterende forskning ved at vise, hvorledes plottet gennem billede og titel allerede etableres på omslaget ved at skabe forventninger om en handling, der vil forene de plotmæssige spor bil, sele i klemme og remsen "spejl, skulder, blink". Disse forventninger er med til at guide læserens fortolkning af, hvad der viser sig at være et bogsta- 
veligt og et metaforisk lag af betydningen af "at skifte (eller ikke skifte) gear", som realiseres gennem romanens kobling af to planer - den aktuelle nutidssituation, hvor Sonja forsøger at lære at køre bil, og et komplekst eksistentielt plan, hvor Sonjas tanker springer i tid og sted. De betydninger, der skabes efterhånden som romanen skrider frem, kan omvendt nødvendiggøre, at læseren justerer sin fortolkning af forsidens betydninger. Vores analyse viser $\mathrm{fx}$, hvordan titlens og billedets betydninger i den videre læsning bliver udvidet til også at omfatte et metaforisk lag. Titlen refererer ikke blot til en køreskolesituation, men også til hovedpersonens konstante bagudskuen, mens den bogstavelige betydning af den røde sele, der er i klemme i bildøren, må forkastes til fordel for en metaforisk fortolkning.

Derudover skaber forlagsnavnet, nomineringsstemplet og anmeldelsen på bogens omslag forventninger om værkets kunstneriske værdi - at forfatterens valg af form og indhold er velovervejede og meningsfulde. Kombinationen af omslagets flertydighed og romanens ukonventionelle brug af afsnit, og-paratakse, citeret tale og tempus ville i andre teksttyper - fx fagtekster - være uhensigtsmæssige, men i Nors' roman accepteres de som litterære virkemidler, der tjener et formål, og som medvirker til at skabe plotmæssig nysgerrighed og fastholde læserens interesse.

En opmærksomhed på det multimodale hjælper os til at forstå, hvordan de ressourcer, der realiserer teksten, inviterer læseren til at indgå i en struktureringsproces, der kan føre til overraskelse, nysgerrighed og spænding i en vekslen mellem tilbageskuende og fremadskuende perspektiver. Romanens form, ikke mindst de pludselige skift mellem planerne i de parataktiske sætningskomplekser, udfordrer læseren. Det gør de, fordi læserens nysgerrighed ikke tilfredsstilles (da hun ikke får noget at vide om det, der mangler, som fx hvorfor Sonja i (11) ikke giver op, selvom hun burde, og hvad det er, hun burde opgive), og fordi hendes spænding ikke forløses (da fortællingen hele tiden skifter retning fx fra ovenstående tanker om at give op og tilbage til instruktørens vejledning på førstehjælpskurset). Vores analyse viser dermed, at en romans tema - i dette tilfælde "undvigelse" - kan realiseres ikke blot på handlingsniveau, men også inden for afsnittet og helt ned på sætningsniveau. Omvendt guider de konventioner, romanen etablerer 
multimodalt ( $\mathrm{fx}$ de forskellige layoutmæssigt, typografisk og sprogligt realiserede former for citeret tale), læseren, så hun kan navigere mellem romanens forskellige planer.

I ovenstående har vi demonstreret, hvordan vores multimodale socialsemiotiske tilgang og deri funderede grammatiske analyser bidrager til at nuancere analysen også af en roman, der ikke er påfaldende multimodal i sit udtryk. Vores artikel bidrager til det socialsemiotiske multimodale forskningsfelt - og mere specifikt den multimodale stilistisk - ved at inkorporere det narratologiske begreb plot i højere grad end hidtil og ved at vise, hvordan plot realiseres multimodalt.

Alexandra Holsting

Centre for Multimodal Communication

Institut for Sprog og Kommunikation

Syddansk Universitet

aho@sdu.dk

Cindie Aaen Maagaard

Centre for Multimodal Communication

Institut for Sprog og Kommunikation

Syddansk Universitet

cindiem@sdu.dk

Nina Nørgaard

Centre for Multimodal Communication

Institut for Sprog og Kommunikation

Syddansk Universitet

noergaard@sdu.dk 


\section{LITTERATUR}

Andersen, T.H. \& A. Holsting. 2015. Teksten i grammatikken. Odense: Syddansk Universitetsforlag.

Barthes, R. 1967. Elements of semiology. New York: Hill \& Wang.

Breindl, E., A. Volodina \& U.H. Waßner. 2014. Handbuch der deutschen Konnektoren 2, bind 1. Boston: de Gruyter.

Brooks, P. 1984. Reading for the plot. Cambridge: Harvard University Press.

Bruner, J. 2001. The narrative construction of reality. Critical Inquiry 18. 1-21.

Chatman, S. 1978. Story and discourse. Narrative structure in fiction and film. Ithaca: Cornell University Press.

Galberg Jacobsen, H. og P. Skyum-Nielsen. 2007. Dansk sprog. En grundbog. København: Schønberg.

Genette, G. 1980. Narrative discourse. An essay in method. Ithaca: Cornell University Press.

Genette, G. 1997 [1987]. Paratexts: Thresholds of interpretation. Cambridge: Cambridge University Press.

Gibbons, A. 2012. Multimodality, cognition, and experimental literature. London: Routledge.

Grice, H.P. 1975. Logic and conversation. P. Cole \& J.L. Morgan (red.), Syntax and semantics, Vol. 3 Speech Acts, 41-58. New York: Academic Press.

Halliday, M.A.K. 1978. Language as a social semiotic. London: Arnold.

Halliday, M.A.K. 1979. Modes of meaning and modes of expression: types of grammatical structure and their determination by different semantic functions. D.J. Allerton, E. Carney \& D. Holdcroft (red.), Function and context in linguistic analysis: Essays offered to William Haas. Cambridge: Cambridge University Press.

Halliday, M.A.K. 1994. An introduction to functional grammar. London: Arnold.

Halliday, M.A.K. \& C.M.I.M. Matthiessen. 2000. Construing experience through meaning: a language-based approach to cognition. London: Continuum.

Halliday, M.A.K. \& C.M.I.M. Matthiessen. 2013. Halliday's introduction to functional grammar. London: Routledge.

Hansen E. \& L. Heltoft. 2011. Grammatik over det danske sprog, bind 1-3. København: Det Danske Sprog- og Litteraturselskab.

Herman, D. 2003. Introduction. D. Herman (red.), Narrative theory and the cognitive sciences, 1-30. Stanford: CSLI.

Hjelmslev, L. 1993 [1943]. Omkring sprogteoriens grundlaggelse. Travaux du Cercle Linguistique de Copenhague XXV. Copenhagen: The Linguistic Circle of Copenhagen.

Hühn, P. 2008. Functions and forms of eventfulness in narrative fiction. J. Pier, J. \& J.A.C. Landa (red.), Theorizing narrativity, 143-163. Berlin: de Gruyter. 
Jacobsen, H.G. \& P.S. Jørgensen. 2013. Håndbog i nudansk. København: Politikens Forlag.

Kafalenos, E. 2001. Reading visual art, making - and forgetting - fabulas. Narrative 9(2). 138-145.

Kress, G. 2010. Multimodality: A social semiotic approach to contemporary communication. London: Routledge.

Kress, G. \& T. van Leeuwen. 1996. Reading images: The grammar of visual design. London: Routledge.

Kress, G. \& T. van Leeuwen. 2001. Multimodal discourse: The modes and media of contemporary communication. London: Arnold.

Kress, G. \& T. van Leeuwen. 2002. Colour as a semiotic mode: Notes for a grammar of colour. Visual Communication 1(3). 343-368.

Kukkonen, K. 2011. Comics as a test-case for transmedial narratology. SubStance 40(1). 34-52. DOI: https://doi.org/10.1353/sub.2011.0005.

Kukkonen, K. 2014a. Bayesian narrative: Probability, plot and the shape of the fictional world. Anglia 132(4). 720-739. DOI 10.1515/anglia-2014-0075.

Kukkonen, K. 2014b. Plot. P. Hühn m.fl. (red.), The living handbook of narratology. Hamburg: Hamburg University. www.lhn.uni- hamburg.de/article/plot. (Tilgået 18.06.2018).

Leeuwen, T. van. 2006. Towards a semiotics of typography. Information design journal + document design 14(2). 139-155.

Leeuwen, T. van. 2011. The language of colour: An introduction. London: Routledge.

Luke, J. 2013. Writing the visible page: A multimodal approach to graphic devices in literary fiction.

Queensland University of Technology: Ph.d.-afhandling. http://eprints.qut. edu.au/63020/. (Tilgået 15.1.2016).

Martin J.R. \& D. Rose. 2003. Working with discourse. London: Continuum.

Maagaard, C.A. 2018. Picturing scripts: A combined narrative, social semiotic and cognitive approach to visual narrativity. Multimodal communication 7(2). https://doi. org/10.1515/mc-2017-0019.

Nors, D. 2016. Spejl, skulder, blink. København: Gyldendal.

Nørgaard, N. 2019. Multimodal stylistics of the novel: More than words. New York: Routledge. https://doi.org/10.4324/9781315145556.

Ryan, M.-L. 2004. Narrative across media. The languages of storytelling. Lincoln: University of Nebraska Press. 
Ryan, M.-L. 2012. Narration in various media. P. Hühn m.fl. (red.), The living handbook of narratology. Hamburg: Hamburg University. http://www.lhn.uni-hamburg.de/ article/narration-various-media. (Tilgået 04.07.2017).

Squires, C. 2007. Book marketing and the Booker Prize. N. Matthews \& N. Moody (red.), Judging a book by its cover: Fans, publishers, designers, and the marketing of fiction, 71-82. Burlington: Ashgate.

Sternberg, M. 1978. Expositional modes and temporal ordering in fiction. Baltimore: Johns Hopkins University Press.

Sternberg, M. 2001. How narrativity makes a difference. Narrative 9(2). 115-122.

Ulbæk, I. 2005. Sproglig tekstanalyse - Introduktion til pragmatisk tekstlingvistik. København: Academia. 